\title{
Imported and locally acquired human myiasis in Canada: a report of two cases
}

\author{
Derek R. MacFadden MD, Brittany Waller MD, Gil Wizen MSc, Andrea K. Boggild MSc MD
}

Competing interests: None declared.

This article has been peer reviewed.

The authors have obtained

Correspondence to: Andrea Boggild, andrea.boggild@utoronto.ca

CMAJ 2015. DOI: 10.1503 /cmaj.140660 patient consent.

$\Lambda$ 45-year-old previously healthy woman presented to the emergency department with a three-week history of swelling and redness around her left eye. About four weeks before the onset of her symptoms, the patient had been camping in Killarney, Ontario, followed by seven days at a cottage in Parry Sound, Ont. A few days after her return home, the patient awoke with what she thought was an insect bite below her left eye. The area was warm, red and tender, and two small spots were visible. Over the next week, substantial swelling developed around the eye, accompanied by sharp, stabbing pain and watery discharge.

In the weeks that followed, the patient made frequent trips to both walk-in clinics and emer-

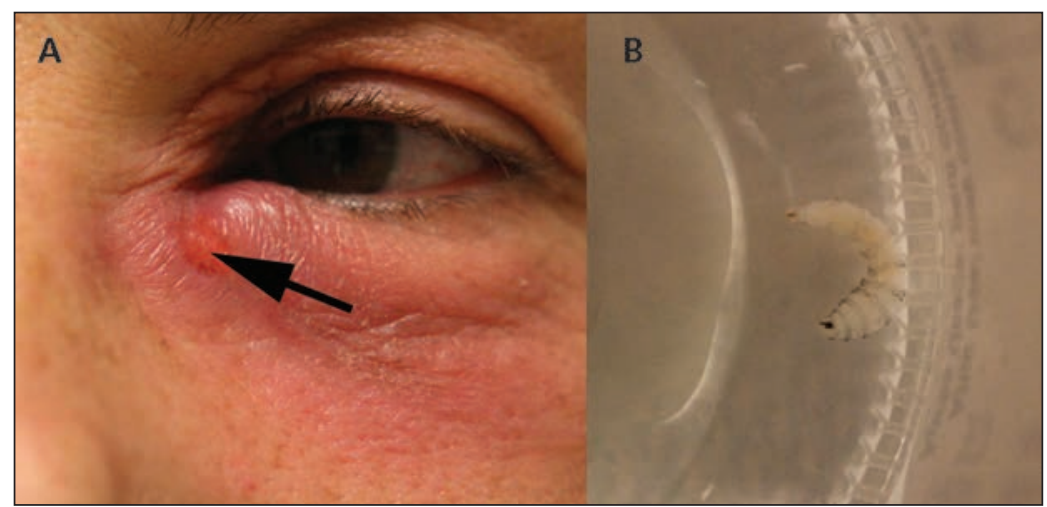

Figure 1: (A) Myiasis caused by Cuterebra species in an otherwise healthy 45-yearold woman. Note the periocular erythema, punctum (arrow) and serosanguinous drainage. (B) An intact, live larva was extruded manually from the periocular lesion.

\section{KeY POINTS}

- Travel to exotic locations is not required to acquire human myiasis infestation.

- Travel-acquired myiasis is typically caused by the human botfly, Dermatobia hominis, or the Tumbu fly, Cordylobia anthropophaga.

- Human myiasis is a clinical diagnosis requiring a compatible epidemiologic history, the sensation of movement or lancinating pain and the presence of a punctate nodule on examination.

- Prompt removal of larvae is required to limit morbidity and the risk of secondary bacterial infection of the skin and soft tissue. gency departments. An initial diagnosis of periorbital cellulitis was treated over several weeks with agents including fucidin antibiotic ointment, cephalexin, ciprofloxacin, cefazolin and clindamycin.

When we assessed her, the patient reported no regular use of medication and had no drug allergies. There was no history of occupational or home exposure that could account for her swelling. On physical examination, we found mild periorbital erythema and edema of the patient's left eye and could see a small punctum toward the left medial canthus (Figure 1A). Shortly before her arrival at the hospital, the patient had extruded a live, intact, larva from the area (Figure 1B). Laboratory identification of the larva confirmed a diagnosis of cutaneous myiasis caused by Cuterebra species. The patient made an uneventful recovery.

A 33-year-old otherwise healthy man was seen in our clinic for an assessment of skin nodules after a 12-day trip to rural Belize. Upon his return from abroad, the patient had noted three red lesions on the left side of his chest. The patient initially interpreted the marks to be mosquito bites. He sought medical attention when he began to feel an itch and sharp pains and noticed a watery red discharge at the site of the lesions. He had no other symptoms.

The patient was otherwise well and reported no regular use of medications or known drug allergies. Born in Israel, the patient had moved to Toronto, Ont., at 31 years of age. His travel history was extensive; however, there was no recent travel other than to Belize. On physical examination, we found three, furuncle-like lesions on the left anterior chest wall, with mild surrounding erythema and spontaneous serosanguineous exudate (Figure 2).

Following occlusion with petroleum jelly, three larvae morphologically consistent with Dermatobia hominis were extracted from the patient's chest using lateral pressure and a commercial venom extractor. ${ }^{1}$ The larvae were removed, and the patient was discharged from 
hospital. His sharp, stabbing pains returned later that night, arising from the three nodules from which the larvae had been removed. By applying petroleum jelly occlusion and lateral pressure at home, the patient was able to extract a fourth larva from the chest wall two weeks later, and a fifth dead larva after three additional weeks (Figure 3). A presumed sixth larval nodule was identified on the patient's anterior chest (Figure 3),

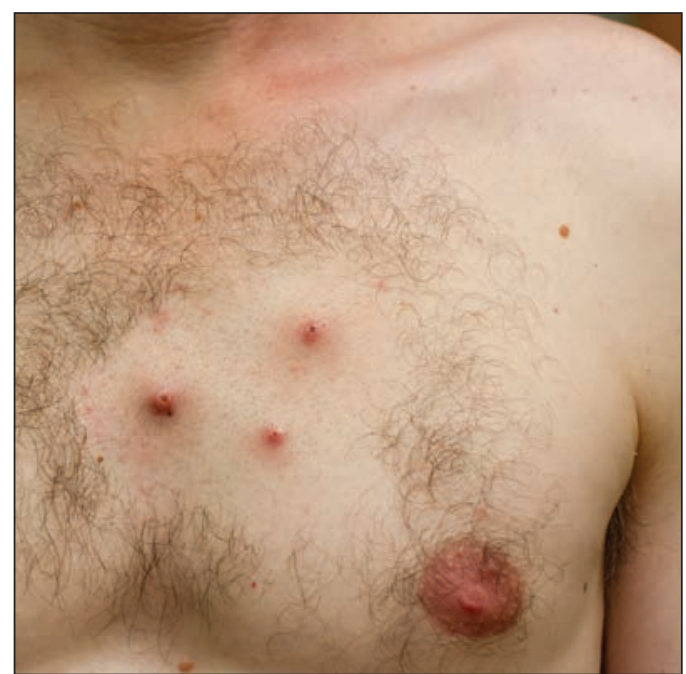

Figure 2: Myiasis caused by Dermatobia hominis in a 33-year-old man. Three domiciles were noted on the patient's anterior chest wall after he returned from Belize. but multiple attempts at extraction were unsuccessful. The patient completed a 10-day course of cephalexin for secondary bacterial infection of the final inhabited nodule, and no further nodules were identified in follow-up. The final inhabited nodule closed spontaneously and has been asymptomatic thereafter.

\section{Discussion}

Myiasis is an infestation of fly larva belonging to the order Diptera. ${ }^{2,3}$ The condition has several cutaneous manifestations, and can present as maggots in a wound, furuncles or migratory lesions. ${ }^{2,3}$ Wound myiasis is the most common form of the condition in humans (although it is likely underreported because it is considered a natural sequelae of poorly managed wounds) and can even be encountered in nosocomial settings. ${ }^{4}$

In North America, most reported cases are acquired during travel from tropical and subtropical climates. ${ }^{3}$ Dermatobia hominis, as in case 2, and Cordylobia anthropophaga are the most frequently implicated species. ${ }^{3}$ Myiasis in humans can be caused by flies native to North America, although people typically represent accidental hosts compared with the flies' usual host species, including livestock (e.g., cattle, goats and sheep) and rodents. ${ }^{2,3,5}$ Flies that cause furuncular myiasis in North America include Hypoderma spe-

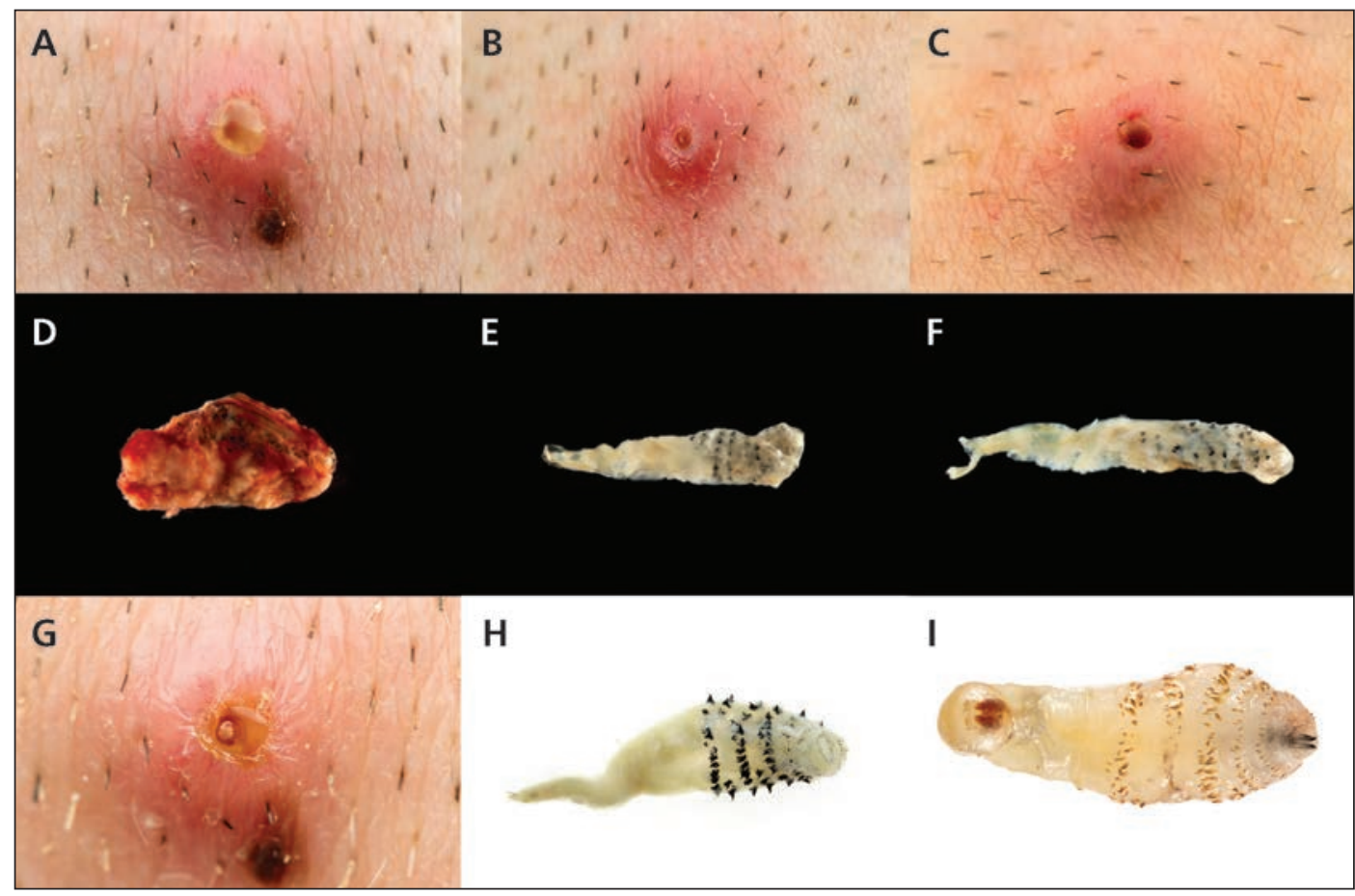

Figure 3: Travel-acquired myiasis caused by Dermatobia hominis in a 33-year-old man. Individual domiciles were visible on the patient's anterior chest $(A-C)$, with erythema and visible puncta. Intact larvae post extraction measured $2.77 \mathrm{~mm}$ (D), $3.87 \mathrm{~mm}$ (E), $5.67 \mathrm{~mm}$ (F), $12.74 \mathrm{~mm}$ (H) and $14.25 \mathrm{~mm}(\mathrm{I})$. Note the radial spines on the surface of the organisms. (G) A presumed sixth larval nodule, which closed spontaneously. The larval spiracles can be seen through the punctum. 
cies, Wohlfahrtia vigil and, as seen in case 1, Cuterebra species. ${ }^{2,3,5}$ After 5 to 10 weeks, the larvae emerge from the skin and fall to the ground, where they will pupate., ${ }^{2,3,5}$

In Canada, 52 cases of furuncular myiasis have been previously reported in the literature (Appendix 1, available at www.cmaj.ca/lookup /suppl/doi:10.1503/cmaj.140660/-/DC1); of these, we identified 8 cases of locally acquired myiasis caused by Cuterebra species (Appendix 1). ${ }^{5}$

\section{Clinical presentation}

The clinical manifestation of myiasis reflects the life cycle of the species responsible for the infestation. Tropical botfly (Dermatobia hominis) lay their eggs on the underside of blood-feeding insects of the order Diptera. When the eggs hatch, they penetrate the host's dermis after the carrier insect feeds. The Tumbu fly (Cordylobia anthropophaga) usually lays its eggs on moist clothing; the larvae can then invade at the point of contact with skin., ${ }^{2,3}$ The scalp, neck, shoulders and chest are the most commonly infested anatomic regions; $;^{2,3}$ however, mucocutaneous and visceral sites, such as the oropharynx, respiratory tract and eyes, can also be involved. ${ }^{3}$

Species native to North America, including Cuterebra, lay their eggs on vegetation and rely on contact between the plant and a potential host for transfer., ${ }^{2,35}$ Larval hatching occurs after the eggs adhere to the host, followed by subdermal migration, often through compromised epithe- lium such as wounds or arthropod bites. ${ }^{2,3,5}$ Consequently, patients with myiasis may recall having an initial skin lesion, which can be caused by either the carrier insect species or some other mechanism. ${ }^{5}$ In our first patient's case, her face may have came into contact with egg-laden vegetation as she emerged from her tent.

The hatching larvae of Dermatobia hominis and Cuterebra species are covered with radial spines that allow them to anchor themselves within the host, whereas Cordylobia anthropophaga are not. The anchoring process can cause lancinating pain, which is commonly reported by patients with myiasis and can be used as a historical feature to differentiate myiasis from other causes of furunculosis. The larva burrows into the host's skin, and the protective pocket that it develops in is referred to as a warble or domicile. ${ }^{5}$ As the larva develops within the host, it feeds on surrounding tissues or fluids. Multiple larvae can exist within adjacent nodules; ${ }^{2,3,5}$ however, our second patient's case is unusual because multiple Dermatobia hominis larvae developed within a single nodule.

One may have a local immune response to the larva, which can resemble secondary bacterial cellulitis. Migratory (creeping) myiasis can have a diffuse reaction as a result of the larva moving through new tissue across a greater surface area. ${ }^{2,3,5}$ Because the larva requires oxygen, it maintains a breathing hole at the surface of the nodule that is visible as a small black punctum

\begin{tabular}{|c|c|c|c|}
\hline Disease & Pathogen & Region & Clinical features \\
\hline Furuncular myiasis & $\begin{array}{l}\text { Dermatobia hominis, } \\
\text { Cordylobia spp., Cuterebra } \\
\text { spp., Hypoderma spp., } \\
\text { Wohlfahrtia spp., others }\end{array}$ & Global & $\begin{array}{l}\text { One or more nodules with } \\
\text { central puncta; may have } \\
\text { sensation of movement or } \\
\text { lancinating pain }\end{array}$ \\
\hline Furunculosis & $\begin{array}{l}\text { Staphylococcus aureus, } \\
\text { Pseudomonas aeruginosa, } \\
\text { polymicrobial infection }\end{array}$ & Global & $\begin{array}{l}\text { Cutaneous abscesses that } \\
\text { can be associated with } \\
\text { adjacent cellulitis }\end{array}$ \\
\hline Tungiasis & Tunga penetrans (sand flea) & $\begin{array}{l}\text { South and Central } \\
\text { America, Africa, } \\
\text { India }\end{array}$ & $\begin{array}{l}\text { Small papule with black } \\
\text { centre that can become } \\
\text { inflamed; typically invades } \\
\text { the feet, including the heel } \\
\text { and toes }\end{array}$ \\
\hline $\begin{array}{l}\text { Nodular } \\
\text { lymphangitis }\end{array}$ & $\begin{array}{l}\text { Sporothrix schenckii. } \\
\text { Mycobacterium spp., } \\
\text { Nocardia spp. }\end{array}$ & Global & $\begin{array}{l}\text { Nodular lesions with spread } \\
\text { via lymphatics with } \\
\text { associated lymphangitis; } \\
\text { classically sporotrichoid or } \\
\text { lymphocuticular spread }\end{array}$ \\
\hline $\begin{array}{l}\text { Cutaneous } \\
\text { leishmaniasis }\end{array}$ & Leishmania spp. & $\begin{array}{l}\text { South and Central } \\
\text { America, Middle } \\
\text { East, Saharan } \\
\text { Africa, South } \\
\text { Central Asia }\end{array}$ & $\begin{array}{l}\text { Typically ulcerative but can } \\
\text { present as nodular or } \\
\text { verrucous plaques }\end{array}$ \\
\hline
\end{tabular}


on the skin..$^{5}$ The larval spiracles, a pair of posterior openings that allow air into the insect's respiratory system, can sometimes be seen through this puncta (Figure 3 ). When the larva is sufficiently large, it may intermittently emerge from the nodule. Pain at the site worsens as the larva grows, and secondary bacterial infections of the skin and soft tissue may occur owing to the presence of the punctum. The larva's emergence from its host upon completion of its development is usually painless because its secretions have local anesthetic effects. ${ }^{6}$

\section{Diagnosis}

Diagnosis of myiasis is clinical and based on the presence of a visible punctum, the sensation of movement at the involved region, lancinating pain and a compatible epidemiologic history. Other causes of nodular skin lesions in travellers should be considered (Box 1). Extraction and examination of the larva confirms the diagnosis. Species are identified by morphological features including size, the structure and shape of spiracles, and the number and pattern of spines.

\section{Treatment}

Extraction of the larvae is recommended because the maturation process can be painful and associated with secondary infection of the soft tissues. Prompt removal of larvae can obviate the need for antibiotics. Larvae with radial spines are more difficult to extract than those without because they are anchored within the nodule. All methods of extraction involve initial skin antisepsis, followed by occlusion of the spiracle to suffocate the larva and cause its emergence. Once the larva is partially exposed, various approaches may be employed to remove it, including vacuum extraction using commercial venom extractors, ${ }^{1}$ direct lateral pressure and, in later stages of development as the larva increases in size, surgery. ${ }^{2,3,5}$ Both vacuum extraction and direct pressure were used to remove the larvae from our second patient. In the case of Tumbu fly larvae, direct lateral pressure is often sufficient for their removal because they lack radial spines. Larvae that die within the nodule may trigger granuloma formation, be extruded spontaneously or be resorbed by the host.

\section{References}

1. Boggild AK, Keystone J, Kain K. Furuncular myiasis: a simple and rapid method for extraction of intact Dermatobia hominis larvae. Clin Infect Dis 2002;35:336-8.

2. Robbins K, Khachemoune A. Cutaneous myiasis: a review of the common types of myiasis. Int J Dermatol 2010;49:1092-8.

3. Delshad E, Rubin A, Almeida L, et al. Cuterebra cutaneous myiasis: case report and world literature review. Int J Dermatol 2018;47:363-6.

4. Szakacs TA, MacPherson P, Sinclair BJ, et al. Nosocomial myiasis in a Canadian intensive care unit. CMAJ 2007;177: 719-20.

5. Caissie R, Beaulieu F, Giroux M, et al. Cutaneous myiasis: diagnosis, treatment, and prevention. J Oral Maxillofac Surg 2008;66: 560-8.

6. Ofordeme KG, Papa L, Brennan DF. Botfly myiasis: a case report. CJEM 2007;9:380-2.

7. O'Brien BM. A practical approach to common skin problems in returning travelers. Travel Med Infect Dis 2009;7:125-46.

Affiliations: Department of Medicine (MacFadden, Waller, Boggild), University of Toronto, Toronto, Ont.; Department of Biology (Wizen), University of Toronto at Mississauga, Ont.; Tropical Disease Unit, Toronto General Hospital and Public Health Ontario Laboratories, Public Health Ontario (Boggild), Toronto, Ont

Contributors: All authors contributed to the literature review, writing, critical appraisal and revision of the manuscript.

The section Cases presents brief case reports that convey clear, practical lessons. Preference is given to common presentations of important rare conditions, and important unusual presentations of common problems. Articles start with a case presentation (500 words maximum), and a discussion of the underlying condition follows (1000 words maximum). Visual elements (e.g., tables of the differential diagnosis, clinical features or diagnostic approach) are encouraged. Written consent from patients for publication of their story is a necessity and should accompany submissions. See information for authors at www.cmaj.ca. 